\title{
Classification Shifting in the Income-Decreasing Discretionary Accrual Firms
}

\author{
Hümeyra Adıgüzel ${ }^{1}$ \\ ${ }^{1}$ Bahçeşehir University, Turkey \\ Correspondence: Hümeyra Adıgüzel, Bahçeşehir University, Turkey.
}

Received: July 5, 2017

Accepted: July 19, 2017

Online Published: July 25, 2017

doi:10.5430/ijfr.v8n3p187

URL: https://doi.org/10.5430/ijfr.v8n3p187

\begin{abstract}
This study investigates whether managers use classification shifting to classify operating expenses as non-operating. Using a methodology similar to McVay (2006), I find no evidence of classification shifting between operating and non-operating expenses. However, I find evidence that managers classify operating expenses as non-operating in the absence of income decreasing accrual management. This finding can be explained that income-decreasing accrual management both affects operating and non-operating expenses and measuring classification shifting without considering discretionary accrual management produces meaningless results.
\end{abstract}

Keywords: classification shifting, non-operating expenses, income-decreasing accrual management

\section{Introduction}

Classification shifting has received attention in recent years as an earnings management tool. It is defined by McVay (2006) as the deliberate misclassification of items within the income statement. Some studies examined the misclassification of core expenses as income decreasing special items (McVay 2006; Fan, Barua, Cready \& Thomas 2010), some as discontinued operations (Barua, Lin, \& Sbaraglia, 2010), and some as non-operating expenses (Noh, Moon, Guiral, \& Esteban 2014). Literature also provides extensive evidence for other two general earnings management tools: accrual management (Healy 1985; DeAngelo 1986; McNichols \& Wilson, 1988; Jones 1991; DeFond \& Jiambalvo 1994; Dechow, Sloan, \& Sweeney 1995; Kothari, Leone, \& Wasley, 2005) and real activities management (Roychowdhury 2006; Cohen \& Zarowin 2010; Gunny 2010; Zang, 2011).

To manage accruals managers use their judgment in financial reporting to choose between accounting policies. They change accounting methods or estimates without changing real activities to manipulate reported earnings in financial statements. On the other hand real activities management affects the normal business practices. Real earnings management can be achieved through timing of sales by providing temporary price discounts, timing of R\&D expenditures, advertising and maintenance expenses, or timing of income recognition from disposal of long-lived assets and investments. Unlike these two forms of earnings management, classification shifting does not change the income of the period or the business practices.

The relationship between these three forms of earnings management has also been investigated in the literature. Athanasakou, Strong, and Walker (2011) explore the market response to achieving analyst earnings expectations associated with three types of earnings management (accrual management, real earnings management, and classification shifting). One of their findings states that UK firms use classification shifting to achieve analyst expectations. They also find that firms that achieve expectations through classification shifting receive a lower market reward than genuine achievers. Abernathy, Beyer, and Rapley (2014) investigate whether managers use classification shifting when their ability to use other forms of earnings management is constrained. They find that classification shifting is a substitute form of earnings management for both real and accrual earnings management.

In this study firstly I examine classification shifting between operating expenses and non-operating expenses in a sample of Turkish firms. Managers could engage in this type of shifting if they think that investors give more attention to operating profit rather than non-operating profit. However I did not find support to classification shifting hypothesis which states that to increase operating profit of the period, managers might classify expenses as non-operating although they are operating in nature. Then I examined classification shifting in the firms who do not manage income through income-decreasing accruals and I find that managers classify operating expenses as 
non-operating if they do not use income decreasing accruals to manage earnings. Managing accruals both affects operating and non-operating expenses, and measuring classification shifting without considering how much of the operating and non-operating expenses deliberately managed through accruals would produce meaningless results. In this study classification shifting is measured by taking into consideration the discretionary management of accruals.

The remainder of the paper is organized as follows. Section 2 reviews the literature and develops testable hypotheses. Section 3 describes data and the sample. Section 4 describes the measurement of classification shifting and reports descriptive statistics. Section 5 reports the empirical results, while section 6 provides the concluding remarks.

\section{Literature Review and Hypothesis Development}

Classification shifting defined by McVay (2006) as the opportunistic misclassification of expense items within the income statement and received a greater degree of attention in the literature (McVay, 2006; Fan et al., 2010; Haw et al., 2011). McVay (2006) investigates whether managers reclassify core expenses to special items. As the first evidence of classification shifting she finds a positive relation between unexpected core earnings and income-decreasing special items. Fan et al. (2010) provide support to the classification shifting model of McVay (2006). They use quarterly data and extend McVay's model by dropping current-period accruals. By using the extended model Fan et al. (2010) find evidence of classification shifting between core earnings and special items. Barua et al. (2010) examine classification shifting between core earnings and income-decreasing discontinued operations and find a positive relationship.

In the study I use non-operating loss firms where the non-operating expenses are higher than the non-operating revenues to test classification shifting between operating and non-operating expenses. Non-operating profits \&losses line item in the financial statements are related with the investing and financing activities of the firm while the operating profit or loss are related with the operating activities of the firm. The Operating Profit is important for financial statement users, as it shows how much profit the company generates from its core business before any revenue or loss from investing and financing activities and taxes. Operating profit represents the earning power of the company with regard to revenues generated from ongoing operations and serves as an indicator to the business's potential profitability. Because of this, I expect a shifting of operating expenses to non-operating expenses. These arguments lead to the following hypothesis:

$\mathbf{H}_{1}$ : Managers classify operating expenses as non-operating expense to increase operating profit.

Examples for the non-operating expenses are losses on asset sales, PP\&E write-offs, Intangible asset write-offs, interest expense and dividend expense. Because most of the expenses in this category can be managed easily through accruals, considering classification shifting without discretionary accrual management may produce meaningless results. Distinguishing how much of these expenses occurred as a result of accrual management will produce more clear findings. McVay (2006) uses contemporaneous accruals in the core earnings expectation model and finds a positive relation between unexpected core earnings and income-decreasing special items. When she removes contemporaneous accruals from the model the positive relationship disappears and becomes negative. McVay (2006) and Fan et al. (2010) explains this as a result of the mechanical relation between unexpected core earnings and accrual-based special items. Abernathy et al. (2014) investigate the relationship between classification shifting and other two earnings management tools. They investigate whether managers use classification shifting when their ability to use real and accrual earnings management is constrained. They find that classification shifting is a substitute form of earnings management for both real and accrual earnings management.

Literature provides evidence of incentives to use income decreasing accruals. One of the incentives is bonus purpose. Bonus plan hypothesis states that managers of firms with bonus plans depended to the current reported earnings try to increase their current bonus by reporting as a high current income as possible. However if they reach their maximum bonus level in the current period they try to choose accounting policies relating to accruals that decrease current reported earnings and increase earnings in the future. Healy (1985) investigates the relationship between managers' accrual management decisions under the earnings-based bonus schemes and finds that the managers are more likely to choose income-decreasing accruals when their bonus plan upper or lower bounds are binding. Holthausen, Larcker, and Sloan (1995) also find that the managers make income-decreasing discretionary accruals after they reach their maximum bonus level. Gaver, Gaver, and Austin (1995) find that when earnings before discretionary accruals exceed the upper bound of the bonus plan, managers select income-decreasing discretionary accruals. 
On the other hand literature provides evidence that binding debt covenants is another incentive for firms to manage income downward. DeAngelo, DeAngelo, and Skinner (1994) find that managers of firms which bind the covenants tend to make income-decreasing accruals to gain more concessions in contractual renegotiations.

I expect that if managers already manage earnings downward through income decreasing accruals the relationship between operating profit and non-operating expenses will be negative because both operating expenses and non-operating expenses affected from income-decreasing accruals. I expect that classification shifting is more predictable in the firms which do not use discretionary income decreasing accruals. This expectation can be expressed as the following hypothesis:

$\mathbf{H}_{2}$ : The classification shifting is more predictable in the firms which do not manage accruals to decrease net income

\section{Data and Sample Selection}

Data are obtained for the years 1994-2014 from the Bloomberg Database. Following McVay (2006) observations with sales of less than 1 million are deleted to avoid outliers, because sales used as a deflator for most of the variables. A minimum of 8 observations per industry per fiscal year are used to estimate expected operating profit. Industries are classified according to Global Industry Classification Standards used by Bloomberg. The full sample has 1638 firm-year observations. Expectation model are applied to the full sample of 1638 firm-year observations. The regression model applied to non-operating loss firms and final sample has 1222 firm-year observations.

\section{Research Methodology}

I first estimate expected operating profit of each firm in the sample. To estimate expected operating profit I use the following expectation model developed by McVay (2006). I drop current period accruals from the McVay's (2006) model following Fan et al. (2010). The following model is estimated for each industry and year.

$$
\mathrm{OP}_{\mathrm{t}}=\beta_{0}+\beta_{1} \text { OP }_{\mathrm{t}-1}+\beta_{2} \text { ATO }_{\mathrm{t}}+\beta_{3} \text { Accruals }_{\mathrm{t}-1}+\beta_{4} \Delta \text { Sales }_{\mathrm{t}}+\beta_{5}{\text { Neg } \Delta \text { Sales }_{\mathrm{t}}}
$$

Where $O P$ is Operating Profit (Sales-COGS- Selling, General, and Administrative Expenses) scaled by sales, $A T O$ is asset turnover ratio, Accruals is the difference between net income before extraordinary items and cash flow from operations scaled by sales, $\Delta$ Sales is the change in sales and Neg $\Delta$ Sales is the percent change in sales if $\Delta$ Sales is less than zero, 0 otherwise. Then, unexpected operating profit is calculated for each firm-year as the difference between actual and expected operating profit.

To test the association between the non-operating loss and unexpected operating profit (Hypothesis 1), the following equation is estimated.

$$
U E-O P_{t}=\beta_{0}+\beta_{1} N o n \_O p_{-} L O S S_{\mathrm{t}}
$$

Where $U E-O P$ is unexpected operating profit scaled by sales where unexpected operating profit calculated as the difference between actual and expected operating profit. Non_OP_Loss is non-operating loss as a percentage of sales multiplied with -1 . Note that higher positive values of non-operating loss mean more non-operating expenses (less non-operating revenues) in the period.

Next I test the likelihood of classification shifting in the income-decreasing accrual firms (Hypothesis 2). The following equation is estimated;

$$
\begin{aligned}
U E-O P_{t}= & \beta_{0}+\beta_{1} \text { Non_Op_Loss }{ }_{\mathrm{t}}+\beta_{2} A b s_{-} I n c D e c_{-} A c c_{t}+\beta_{3} \text { Non_Op_Loss }{ }_{\mathrm{t}}^{*} \text { Abs } \text { IncDec_Acc }_{t}+\beta_{4} \text { LogAssets }+ \\
& \beta_{5} \text { Leverage }
\end{aligned}
$$

The dependent variable of the model is unexpected change in the operating profit scaled by sales. Unexpected operating profit is calculated as the difference between the actual and expected operating profit where the expected value is calculated using the McVay's (2006) prediction model (model 1). The variable Non_Op_Loss is defined as the non-operating loss scaled by sales and multiplied with -1 .

Abs_IncDec_Acc variable is the absolute value of income decreasing discretionary accruals scaled by assets where discretionary accruals are calculated from the performance-adjusted cross-sectional variation of the modified Jones' model (Kothari et al. 2005). For each year and for each industry group, total accruals are modeled as a function of change in revenues adjusted for the change in receivables, the level of plant, property and equipment, and Return on Asset, using the following cross-sectional OLS regression model;

$$
\mathrm{TA}_{\mathrm{t}} / \mathrm{A}_{\mathrm{t}-1}=\beta_{0}+\alpha\left[1 / \mathrm{A}_{\mathrm{t}-1}\right]+\beta_{1}\left[\left(\Delta \text { Sales }_{\mathrm{t}}-\Delta \mathrm{AR}_{\mathrm{t}}\right) / \mathrm{A}_{\mathrm{t}-1}\right]+\beta_{2}\left[\mathrm{PPE}_{\mathrm{t}} / \mathrm{A}_{\mathrm{t}-1}\right]+\beta_{3} \mathrm{ROA}_{\mathrm{t}-1}+\varepsilon_{\mathrm{t}}
$$

Income-increasing discretionary accruals are set to zero. The impact of income-decreasing discretionary accruals on the association between unexpected operating profit and non-operating loss is examined by including an interaction 
variable between Non_Op_Loss and Abs_IncDec_Acc (Non_Op_Loss ${ }_{t}^{*}$ Abs_IncDec_Acc $)$. LogAssets is the log of assets which is used to control for systematic variations in unexpected operating profit related to the firm size. Leverage is measured as the total assets divided by total liabilities.

Table 1. Descriptive statistics of the unexpected operating profit prediction model

\begin{tabular}{lrrrrrr}
\hline Variable & \multicolumn{1}{l}{ Mean } & $\underline{\text { Median }}$ & $\underline{\text { Std. Dev. }}$ & $\underline{\text { Min }}$ & $\underline{\text { Max }}$ \\
Sales (in millions) & 1188.436 & 200.592 & 5091.143 & & 1.442 & 69767.140 \\
OP & 0.076 & 0.078 & 0.313 & -9.310 & 0.534 \\
UE- OP & 0.000 & 0.000 & 0.154 & -2.879 & 3.202 \\
Accruals & -15.979 & -1.911 & 330.435 & -7 & 053.172 & 7524.675 \\
Accruals/Sales & -0.102 & -0.015 & 3.577 & -136.857 & 33.304 \\
Asset Turnover Ratio & 1.054 & 0.984 & 0.569 & 0.005 & 4.376 \\
\hline
\end{tabular}

\section{Variables:}

$O P$ : Operating Profit calculated as (Sales-COGS- Selling, General, and Administrative Expenses)/Sales

$U E-O P$ : Unexpected Operating profit scaled by sales where unexpected operating profit is the difference between actual and expected operating profit where the expected value is calculated using the coefficients from model 1;

$\mathrm{OP}_{\mathrm{t}}=\beta_{0}+\beta_{1} \mathrm{OP}_{\mathrm{t}-1}+\beta_{2} \mathrm{ATO}_{\mathrm{t}}+\beta_{3}$ Accruals $_{\mathrm{t}-1}+\beta_{4} \Delta$ Sales $_{\mathrm{t}}+\beta_{5} \mathrm{Neg} \Delta$ Sales $_{\mathrm{t}}$

ATO: Asset Turnover Ratio calculated as; Net Sales / ((Total Assets ${ }_{\mathrm{t}}+{\left.\left.\text { Total } \text { Assets }_{\mathrm{t}-1}\right) / 2\right)}_{2}$

Accruals: Net Income Before Extraordinary Items-Cash Flow From Operations

$\Delta$ Sales : $\left(\right.$ Sales $_{\mathrm{t}}-$ Sales $\left._{\mathrm{t}-1}\right) /$ Sales $_{\mathrm{t}-1}$

Neg $\Delta$ Sales: $\quad$ percent change in sales if $\Delta$ Sales is less than zero, 0 otherwise

Table 1 provides descriptive statistics for the variables used in unexpected operating profit prediction model (model 1). Mean sales revenue for all firms is 1188.436 million TL, and median is 200.592 million TL. Minimum sales revenue in TL is 1.442 million while maximum sales revenue is 69767.140 million TL. Operating profit scaled by sales has a mean value of 0.076 and median value of 0.078 . The mean and median values of unexpected operating profit scaled by sales are zero. Mean and median of accruals are -15.979 million TL and -1.911 million TL respectively. The mean asset turnover ratio is 1.054 and median is 0.984 .

Table 2. Descriptive statistics of the final sample

\begin{tabular}{llllll}
\hline Variable & $\underline{\text { Mean }}$ & $\underline{\text { Median }}$ & $\underline{\text { Std. Dev. }}$ & $\underline{\text { Min }}$ & \multicolumn{1}{c}{ Max } \\
\hline UE-OP & 0.000 & 0.000 & 0.154 & -2.879 & 3.202 \\
Non_Op_Loss & 0.111 & 0.027 & 0.636 & 0.001 & 17.781 \\
Abs_IncDec_Acc & 0.223 & 0.000 & 3.440 & 0.000 & 115.092 \\
LogAssets & 5.592 & 5.465 & 1.585 & 2.054 & 11.499 \\
Leverage & 3.679 & 2.402 & 5.843 & 0.190 & 122.997 \\
\hline
\end{tabular}

Variables:

$U E$ - OP: Unexpected Operating profit scaled by sales where unexpected operating profit is the difference between actual and expected operating profit where the expected value is calculated using the coefficients from model 1 ;

$\mathrm{OP}_{\mathrm{t}}=\beta_{0}+\beta_{1} \mathrm{OP}_{\mathrm{t}-1}+\beta_{2}$ ATO $_{\mathrm{t}}+\beta_{3}$ Accruals $_{\mathrm{t}-1}+\beta_{4} \Delta$ Sales $_{\mathrm{t}}+\beta_{5}$ Neg $\Delta$ Sales $_{\mathrm{t}}$ 
Non_Op_Loss: Non-operating loss as a percentage of sales multiplied with -1 .

LogAssets: Log of total assets

Leverage: Total Assets/ Total Liabilities

Abs_IncDec_Acc: Absolute value of income decreasing discretionary accruals (for the income increasing accruals the value is set to 0 ) calculated using the coefficients from model 4 applied for each year and for each industry group;

$\mathrm{TA}_{\mathrm{t}} / \mathrm{A}_{\mathrm{t}-1}=\beta_{0}+\alpha\left[1 / \mathrm{A}_{\mathrm{t}-1}\right]+\beta_{1}\left[\left(\Delta \mathrm{Sales}_{\mathrm{t}}-\Delta \mathrm{AR}_{\mathrm{t}}\right) / \mathrm{A}_{\mathrm{t}-1}\right]+\beta_{2}\left[\mathrm{PPE}_{\mathrm{t}} / \mathrm{A}_{\mathrm{t}-1}\right]+\beta_{3} \mathrm{ROA}_{\mathrm{t}-1}+\varepsilon_{\mathrm{t}}$

$\mathrm{TA}=$ total accruals

$\Delta$ Sales $=$ revenues in year $\mathrm{t}$ less revenues in year $\mathrm{t}-1$

$\Delta \mathrm{AR}=$ net receivables in year $\mathrm{t}$ less net receivables in year $\mathrm{t}-1$

$\mathrm{PPE}=$ gross property, plant, and equipment in year $\mathrm{t}$

$\mathrm{ROA}=$ return on asset in year $\mathrm{t}$

$\mathrm{A}=$ total assets

Table 2 provides descriptive statistics for the variables used in empirical analysis. The mean and median values of unexpected operating profit scaled by sales are zero. Minimum unexpected operating profit scaled by sales is -2.879 and maximum value is 3.202. Non_Op_Loss variable has a mean value of 0.111 and median value of 0.027 . The minimum value of $A b s \_I n c D e c \_A c c$ variable is zero because income-increasing accruals in the model are set to zero. The mean and median values of absolute value of income-decreasing accruals are 0.223 and 0.000 respectively. The mean values of LogAssets and Leverage variables are 5.592 and 3.679 respectively.

\section{Results}

Table 3. Pearson Correlations

\begin{tabular}{lccccc}
\hline & UE-OP & Non_Op_Loss & Abs_IncDec_Acc & LogAssets & Leverage \\
\hline UE-OP & 1.000 & & & \\
Non_Op_Loss & -0.036 & 1.000 & & \\
& $(0.211)$ & & & \\
Abs_IncDec_Acc & $\mathbf{- 0 . 0 6 8}$ & 0.015 & 1.000 & \\
& $\mathbf{( 0 . 0 1 8 )}$ & $(0.604)$ & & 1.000 \\
LogAssets & 0.000 & -0.015 & -0.031 & & \\
& $(0.992)$ & $(0.612)$ & $(0.282)$ & $\mathbf{- 0 . 1 1 6}$ & 1.000 \\
Leverage & $\mathbf{0 . 0 7 7}$ & $\mathbf{0 . 1 0 7}$ & -0.006 & $\mathbf{( 0 . 0 0 0 )}$ &
\end{tabular}

\section{Variables:}

$U E-O P$ : Unexpected Operating profit scaled by sales where unexpected operating profit is the difference between actual and expected operating profit where the expected value is calculated using the coefficients from model 1 ;

$\mathrm{OP}_{\mathrm{t}}=\beta_{0}+\beta_{1} \mathrm{OP}_{\mathrm{t}-1}+\beta_{2} \mathrm{ATO}_{\mathrm{t}}+\beta_{3}$ Accruals $_{\mathrm{t}-1}+\beta_{4} \Delta$ Sales $_{\mathrm{t}}+\beta_{5}{\text { Neg } \Delta \text { Sales }_{\mathrm{t}}}$

Non_Op_Loss: Non-operating loss as a percentage of sales multiplied with -1 .

$A b s \_I n c D e c \_A c c$ : Absolute value of income decreasing discretionary accruals calculated using the coefficients from model 4 , for the income increasing accruals the value is set to 0 .

LogAssets: Log of total assets

Leverage: Total Assets/ Total Liabilities 
Table 3 shows the Pearson correlations among variables used in empirical analysis. Significant correlation coefficients are shown in bold. The negative and significant correlation coefficient $(-0.068)$ between $A b s \_I n c D e c \_A c c$ and $U E-O P$ suggests unexpected operating profit is lower for the firms who use income decreasing discretionary accruals to manage income of the period. The positive and significant coefficient between Leverage and $U E-O P$ indicates levered firms are more likely classify operating expenses as non-operating. Consistent with the prior literature I find a positive and significant coefficient between Leverage and Abs_IncDec_Acc (DeAngelo, DeAngelo, \& Skinner, 1994). The positive and significant coefficient between Leverage and Abs_IncDec_Acc states that levered firms manage accruals to decrease net income of the period. The correlation coefficients between variables are not large enough to affect the multiple regression analysis.

Table 4. Multiple Regression Results

\begin{tabular}{|c|c|c|c|c|}
\hline \multirow[b]{2}{*}{$\underline{\text { Variable }}$} & \multicolumn{2}{|c|}{ Model 2} & \multicolumn{2}{|c|}{ Model 3} \\
\hline & $\begin{array}{c}\text { Predicted } \\
\quad \underline{\text { Sign }}\end{array}$ & $\begin{array}{c}\text { Coefficient } \\
\text { (z-statistics) }\end{array}$ & $\begin{array}{l}\text { Predicted } \\
\quad \text { Sign }\end{array}$ & $\begin{array}{c}\text { Coefficient } \\
\text { (z-statistics) }\end{array}$ \\
\hline Intercept & & $\begin{array}{c}-0.0001 \\
(-0.01)\end{array}$ & & $\begin{array}{c}-0.0131 \\
(-0.92)\end{array}$ \\
\hline Non_Op_Loss & + & $\begin{array}{c}-0.0096 \\
(-1.37)\end{array}$ & + & $\begin{array}{l}0.0101 \\
(1.69)^{*}\end{array}$ \\
\hline Abs_IncDec_Acc & & & $?$ & $\begin{array}{c}0.0006 \\
(0.58)\end{array}$ \\
\hline Non_Op_Loss ${ }_{\mathrm{t}}{ }^{*} A b s_{-} I n c D e c \_A c c$ & & & - & $\begin{array}{c}-0.0687 \\
(-21.67)^{* * *}\end{array}$ \\
\hline LogAssets & & & ? & $\begin{array}{c}0.0013 \\
(0.54)\end{array}$ \\
\hline Leverage & & & ? & $\begin{array}{c}0.0023 \\
(3.55)^{* * *}\end{array}$ \\
\hline$\overline{\text { Adjusted } R^{2}}$ & $0.01 \%$ & & $49 \%$ & \\
\hline$C h i^{2}$ & 1.89 & & 490.93 & \\
\hline Number of Observations & 1222 & & 1222 & \\
\hline Number of firms & 139 & & 139 & \\
\hline Period & 1994-2014 & & 1994-2014 & \\
\hline
\end{tabular}

Variables:

$U E-O P$ : Unexpected Operating profit scaled by sales where unexpected operating profit is the difference between actual and expected operating profit where the expected value is calculated using the coefficients from model 1;

$\mathrm{OP}_{\mathrm{t}}=\beta_{0}+\beta_{1} \mathrm{OP}_{\mathrm{t}-1}+\beta_{2}$ ATO $_{\mathrm{t}}+\beta_{3}$ Accruals $_{\mathrm{t}-1}+\beta_{4} \Delta$ Sales $_{\mathrm{t}}+\beta_{5}$ Neg $\Delta$ Sales $_{\mathrm{t}}$

Non_Op_Loss: Non-operating loss as a percentage of sales multiplied with -1 .

Abs_IncDec_Acc: Absolute value of income decreasing discretionary accruals (for the income increasing accruals the value is set to 0 ) calculated using the coefficients from model 4 applied for each year and for each industry group as;

$\mathrm{TA}_{\mathrm{t}} / \mathrm{A}_{\mathrm{t}-1}=\beta_{0}+\alpha\left[1 / \mathrm{A}_{\mathrm{t}-1}\right]+\beta_{1}\left[\left(\Delta\right.\right.$ Sales $\left.\left._{\mathrm{t}}-\Delta \mathrm{AR}_{\mathrm{t}}\right) / \mathrm{A}_{\mathrm{t}-1}\right]+\beta_{2}\left[\mathrm{PPE}_{\mathrm{t}} / \mathrm{A}_{\mathrm{t}-1}\right]+\beta_{3} \mathrm{ROA}_{\mathrm{t}-1}+\varepsilon_{\mathrm{t}}$

$\mathrm{TA}=$ total accruals

$\Delta$ Sales $=$ revenues in year $\mathrm{t}$ less revenues in year $\mathrm{t}-1$

$\triangle \mathrm{AR}=$ net receivables in year $\mathrm{t}$ less net receivables in year $\mathrm{t}-1$

$\mathrm{PPE}=$ gross property, plant, and equipment in year $\mathrm{t}$

$\mathrm{ROA}=$ return on asset in year $\mathrm{t}$

$\mathrm{A}=$ total assets

LogAssets: Log of total assets

Leverage: Total Assets/ Total Liabilities 
Table 4 reports the estimation results for models 2 and 3. Model 2 examines the association between the non-operating loss and unexpected operating profit to test Hypothesis 1 . The coefficient of -0.0096 on Non_Op_Loss is not significant to provide support for $\mathrm{H} 1$. Contrary to prior findings there is a negative relationship between Non_OP_Loss and $U E-O P$ which means that when non-operating expenses increases (or non-operating revenues decreases) unexpected change in operating profit decreases. This finding does not provide support to Classification Shifting Theory of McVay (2006). I can explain this finding by the effect of income-decreasing discretionary accruals to both operating and non-operating expenses. I expect that if managers already manage earnings downward through income decreasing accruals the relationship between operating profit and non-operating loss will be negative because both operating expenses and non-operating expenses may increase because of income-decreasing accruals. To test this expectation Hypothesis 2 developed and Model 3 is used. The results of Model 3 show a significant and positive coefficient between UE-OP and Non_Op_Loss. This finding indicates that the managers of the firms, who do not use income decreasing discretionary accruals, misclassify operating expenses as non-operating. The significant and negative coefficient between $U E-O P$ and Non_OP_Loss * Abs_IncDec_Acc interaction variable turns the relationship between $U E-O P$ and Non_OP_Loss to negative as expected. I find a negative relationship between unexpected operating profit and non-operating loss in the firms who manage income by using income-decreasing discretionary accruals.

\section{Conclusion}

Prior literature has investigated classification shifting of core expenses as income decreasing special items (McVay 2006; Fan et al. 2010), classification shifting of core expenses as discontinued operations (Barua et al., 2010), classification shifting of operating expenses as non-operating expenses (Noh et al. 2014). Their findings support the hypothesis that managers deliberately misclassify line items in the income statement to affect the perceptions of financial statement users. In the expectation model used by previous studies accruals are used to control performance. The reason for this is that extreme performance is highly correlated with changes in accrual levels. However as it is stated by McVay (2006), inclusion of accruals to the model may result in possible bias because the accruals can be discretionary and both core expenses and special items can be affected from accrual management.

This study first investigates the classification of operating expenses as non-operating in the income statement by using the expectation model developed by McVay (2006). Contemporary accruals are not included in the model following Fan et al. (2010). I find no significant evidence of classification shifting between operating and non-operating expenses if I ignore the discretionary part of the accrual operating and non-operating expenses. Second I examine the classification shifting for the firms which manage earnings by using income-decreasing accruals. I state that if managers already manage earnings downward through accruals there will be a negative relationship between operating profit and non-operating expenses because both of them is affected from discretionary accruals. For the firms which do not manage accruals the relationship will be positive indicating classification shifting. Findings of the study support these statements.

\section{References}

Abernathy, J. L., Beyer, B., \& Rapley, E. T. (2014). Earnings management constraints and classification shifting. Journal of Business Finance \& Accounting, 41(5-6), 600-626. https://doi.org/10.1111/jbfa.12076

Athanasakou, V., Strong, N. C., \& Walker, M. (2011). The market reward for achieving analyst earnings expectations: does managing expectations or earnings matter?. Journal of Business Finance \& Accounting, 38(1-2), 58-94. https://doi.org/10.1111/j.1468-5957.2010.02219.x

Barua, A., Lin, S., \& Sbaraglia, A. M. (2010). Earnings management using discontinued operations. The Accounting Review, 85(5), 1485-1509. https://doi.org/10.2308/accr.2010.85.5.1485

Cohen, D. A., \& Zarowin, P. (2010). Accrual-based and real earnings management activities around seasoned equity offerings. Journal of accounting and Economics, 50(1), 2-19. https://doi.org/10.1016/j.jacceco.2010.01.002

DeAngelo, H., DeAngelo, L., \& Skinner, D. J. (1994). Accounting choice in troubled companies. Journal of accounting and economics, 17(1), 113-143. https://doi.org/10.1016/0165-4101(94)90007-8

DeAngelo, L.E. (1986). Accounting numbers as market valuation substitutes: a study of management buyouts of public stockholders. The Accounting Review, 61(3), 400-420.

Dechow, P.M., R.G. Sloan, \& Sweeney, A.P. (1995). Detecting earnings management. The Accounting Review, 70(2), 193-225.

DeFond, M.L., \& Jiambalvo, J. (1994). Debt covenant violation and manipulation of accruals. Journal of Accounting 
and Economics, 17, 145-176. https://doi.org/10.1016/0165-4101(94)90008-6

Fan, Y., Barua, A., Cready, W. M., \& Thomas, W. B. (2010). Managing earnings using classification shifting: Evidence from quarterly special items. The Accounting Review, 85(4), 1303-1323. https://doi.org/10.2308/accr.2010.85.4.1303

Gaver, J.J., K. M. Gaver, \& Austin, J. R. (1995). Additional evidence on bonus plans and income management. Journal of Accounting and Economics, 19(3), 3-28. https://doi.org/10.1016/0165-4101(94)00358-C

Gunny, K. A. (2010). The relation between earnings management using real activities manipulation and future performance: Evidence from meeting earnings benchmarks. Contemporary Accounting Research, 27(3), 855-888. https://doi.org/10.1111/j.1911-3846.2010.01029.x

Haw, I. M., Ho, S. S., \& Li, A. Y. (2011). Corporate governance and earnings management by classification shifting. Contemporary Accounting Research, 28(2), 517-553. https://doi.org/10.1111/j.1911-3846.2010.01059.x

Healy, P.M. (1985). The effect of bonus schemes on accounting decision. Journal of Accounting and Economics, 7 , 85-107. https://doi.org/10.1016/0165-4101(85)90029-1

Holthausen, R., D. Larcker, \& Sloan, R. (1995). Annual bonus schemes and the manipulation of earnings. Journal of Accounting and Economics, 19, 29-74. https://doi.org/10.1016/0165-4101(94)00376-G

Jones, J. J. (1991). Earnings management during import relief investigations. Journal of Accounting Research, 193-228. https://doi.org/10.2307/2491047

Kothari, S.P., Leone, A.J., \& Wasley, C.E. (2005). Performance adjusted discretionary accrual measures. Journal of Accounting and Economics, 39, 163-197. https://doi.org/10.1016/j.jacceco.2004.11.002

McNichols, M., \& Wilson, G. (1988). Evidence of Earnings Management from the Provision for Bad Debts. Journal of Accounting Research, 26, 1-31. https://doi.org/10.2307/2491176

McVay, S. E. (2006). Earnings management using classification shifting: An examination of core earnings and special items. The Accounting Review, 81(3), 501-531. https://doi.org/10.2308/accr.2006.81.3.501

Noh, M., Moon, D., Guiral, A., \& Esteban, L. P. (2014). Earnings Management Using Income Classification Shifting-Evidence from the Korean IFRS Adoption Period. Working Paper, 1911-1951.

Roychowdhury, S. (2006). Earnings management through real activities manipulation. Journal of Accounting and Economics, 42, 335-370. https://doi.org/10.1016/j.jacceco.2006.01.002

Zang, A. Y. (2011). Evidence on the trade-off between real activities manipulation and accrual-based earnings management. The Accounting Review, 87(2), 675-703. https://doi.org/10.2308/accr-10196 